\title{
CATALYTIC OXIDATION OF CYCLOHEX-2-ENOL AT POROUS IRON ZEOLITE-LIKE MATERIAL: IN VESTIGATIONS BY GC/MS, POLAROGRAPHY AND X-RAY POWDER DIFFRACTION
}

\author{
Khalid Hamad Abu-Shandi, *
}

https://doi.org/10.23939/chcht12.02.147

\begin{abstract}
The polymeric complexes of porous iron phosphates $\left(\mathrm{NH}_{4}\right)_{4} \mathrm{Fe}_{3}{ }_{3} \mathrm{II}(\mathrm{OH})_{2} \mathrm{~F}_{2}\left[\mathrm{H}_{3}\left(\mathrm{PO}_{4}\right)_{4}\right](\mathbf{1}),\left(\mathrm{C}_{3} \mathrm{H}_{12} \mathrm{~N}_{2}\right)$ $\mathrm{Fe}_{6}{ }_{6}\left(\mathrm{H}_{2} \mathrm{O}\right)_{4}\left[\mathrm{~B}_{4} \mathrm{P}_{8} \mathrm{O}_{32}(\mathrm{OH})_{8}\right](2)$, and $\left\{\left[\mathrm{Fe}^{\mathrm{II}}\left(\mathrm{H}_{2} \mathrm{PO}_{4}\right)_{2}-(\mu-\right.\right.$ 4,4'-bipy) $\left.\left(\mathrm{H}_{2} \mathrm{O}\right)\right] \cdot \mathrm{H}_{2} \mathrm{O} \cdot\left(4,4^{\prime}\right.$-bipy $\left.)\right\}$ (3) were successfully tested towards oxidation of cyclohex-2-enol. The resulting products have been monitored and characterized using gas chromatography/mass spectroscopy, IR spectroscopy, and elemental analysis. Structural properties of the polymeric complexes have been studied using powder X-ray diffraction and electrochemical measurements. The results indicate that these complexes display an irreversible redox process and have high thermal stability. The results also indicated that these complexes undergo a phase change as evidenced by the change of the state of oxidation of metal centres.
\end{abstract}

Keywords: catalytic oxidation, zeolite-like material, GC/MS, polarography, X-ray powder diffraction, cyclohex-2-enol.

\section{Introduction}

In recent, considerable attention has been paid to coordination compounds, which have potential application as molecular wires [1, 2], sensors [3], and thermally stable catalysts [4]. Although numerous metal complexes have been synthesized possessing excellent electrochemical properties and high catalytic activity, they suffer disadvantages such as poor thermal stability and difficulties during wet processing [5].

Zeolites and zeolite-like polymeric complex materials have good thermal stability, highly adjustable electronic conductivity, excellent processability [6], and high catalytic activity [7]. Especially when transition metals are connected by inorganic units as a bridge, the formed conjugated polymers are apt to improve longdistance electronic communication due to delocalization

\footnotetext{
${ }^{1}$ Department of Chemistry, Faculty of Science,

Technical Tafila University, P. O. Box 179, Tafila 66110-Jordan.

*khalidshandi@yahoo.com

C)Abu-Shandi K., 2018
}

[8-12]. Therefore, various types of coordination polymeric complexes have been extensively investigated [13]. These zeolites and zeolite-like polymeric complex materials have irreversibly switchable redox active sites and they can selectively adjust the electron density by oxidation or reduction [7]. In addition, these thermally stable polymeric complexes will not undergo substantial loss in the high temperature reactions [4].

Catalysis reactions have been investigated by spectrophotometric, chemiluminescence and chromatographic methods $[14,15]$, but polarographic measurements of these reactions have not been reported. This motivated us to study the electrochemical properties of iron phosphates during catalytic reactions. Here, we report the results of the electrochemical behavior and powder X-ray diffraction of some iron phosphates before and after catalytic reactions. The purpose of the present study was to investigate the use of three iron phosphates of formulas $\left(\left(\mathrm{NH}_{4}\right)_{4} \mathrm{Fe}_{3}{ }^{\mathrm{II}}(\mathrm{OH})_{2} \mathrm{~F}_{2}\left[\mathrm{H}_{3}\left(\mathrm{PO}_{4}\right)_{4}\right] \quad\right.$ (1), $\left(\mathrm{C}_{3} \mathrm{H}_{12} \mathrm{~N}_{2}\right) \mathrm{Fe}^{\mathrm{II}}{ }_{6}\left(\mathrm{H}_{2} \mathrm{O}\right)_{4}\left[\mathrm{~B}_{4} \mathrm{P}_{8} \mathrm{O}_{32}(\mathrm{OH})_{8}\right] \quad$ (2) and $\left\{\left[\mathrm{Fe}^{\text {III }}\left(\mathrm{H}_{2} \mathrm{PO}_{4}\right)_{2}-\left(\mu-4,4^{\prime}-\right.\right.\right.$-bipy $\left.)\left(\mathrm{H}_{2} \mathrm{O}\right)\right] \cdot \mathrm{H}_{2} \mathrm{O} \cdot(4,4$ '-bipy $\left.)\right\} \quad$ (3)) to catalyze the oxidation of cyclohex-2-enol. The resulting catalytic products have been characterized using gas chromatography/mass spectroscopy, IR spectroscopy and elemental analysis. The methods used in the study proved to be very powerful as analytical techniques for the study of catalytic properties of iron phosphates.

\section{Experimental}

\subsection{Catalytic Reaction Setup for $\mathbf{G}$ as Chromatography/M ass Spectroscopy}

The oxidation reactions were performed in a highpressure stainless-steel autoclave. The autoclave has an internal diameter of $2.5 \mathrm{~cm}$ and an internal volume of $60 \mathrm{ml} .100 \mathrm{mg}$ of iron phosphate adduct was charged in the stainless-steel autoclave under completely dry system 
and under argon. Cyclohex-2-enol (14.7 g) was added to the stainless-steel autoclave using a dry syringe. Toluene (internal standard) $(1.1 \mathrm{ml}, 1 \mathrm{~g})$ was added to the reaction mixture under argon. Dry air was fed under a pressure of $1.8 \mathrm{MPa}$ into the reaction autoclave. An aliquot $(500 \mu \mathrm{l})$ was taken from the reaction mixture as a blank sample. Then the autoclave was sealed and heated to the desired temperature of $423 \mathrm{~K}$. After $6 \mathrm{~h}$ the heating was stopped and the autoclave was cooled to room temperature. A small aliquot $(500 \mu \mathrm{l})$ of the reaction mixture was removed and poured into $2 \mathrm{ml}$ vial with a septum. This was achieved using a liquid sampling syringe. Dry air was applied again in the autoclave (pressure 1.8 MPa). The closed vial was stored in a refrigerator $(275 \mathrm{~K})$ until GC/MS analysis. The heating of the reaction was started again and sampling was repeated after 12, 24, 36, 48, 60 and $72 \mathrm{~h}$ to follow the reaction.

\subsection{G as Chromatography/M ass Spectroscopy}

This instrument is used to monitor the catalytic oxidation reaction of cyclohex-2-enol at $423 \mathrm{~K}$ as described in the previous section. The gas chromatograph is equipped with an ultra 2 column (stationary phase cross-linked Ph-Me-Silicone, length $50 \mathrm{~m}$, outer diameter $0.2 \mathrm{~mm}$, inner diameter $0.11 \mathrm{~mm}$ ). The gas chromatograph was Agilent Technology type 7890 GC equipped with a mass spectrometer type 5975C Inert MSD triple axes detector. The carrier gas was helium $(99.999 \%)$ with a flow rate of $0.60 \mathrm{ml} / \mathrm{min}$. The makeup gas for the mass spectrometer was highly pure argon $(99.999 \%)$, at a flow rate of $19 \mathrm{ml} / \mathrm{min}$. All injections were performed manually using $1 \mu \mathrm{l}$ syringe; the injection volume was $0.2 \mu \mathrm{l}$.

\subsection{Catalytic Reaction Setup for Polarography M easurements}

The reaction setup for polarography measurements is similar to that for the catalytic reaction setup for gas chromatography/mass spectroscopy. The autoclave was sealed and heated to a temperature of $423 \mathrm{~K}$. After $6 \mathrm{~h}$, the heating was stopped and the autoclave was cooled to room temperature. The iron phosphate catalyst was collected by a vacuum filtration using cellulose filter papers and dried under vacuum at a temperature of $313 \mathrm{~K}$. The iron phosphate was stored under argon until polarography measurements. This reaction was repeated with change times of heating after 12, 24, 36, 48, 60 and $72 \mathrm{~h}$.

\subsection{Standard Solutions for Polarographic M easurements}

Sodium pyrophosphate solution $0.10 \mathrm{~mol} / \mathrm{l}$ dissolved in water was used as a background electrolyte.
Ammonium ferrous sulphate hexahydrate was used as $\mathrm{Fe}$ (II) standard (solution $\mathrm{Fe}(\mathrm{II})=1.0 \mathrm{~g} / \mathrm{l}$ ), and ammonium iron (III) sulphate dodecahydrate was used as Fe(III) standard (solution $\mathrm{Fe}(\mathrm{III})=1.0 \mathrm{~g} / \mathrm{l}$ ). $\mathrm{Fe}$ (II) and $\mathrm{Fe}(\mathrm{III})$ standards were dissolved in $50 \% \mathrm{v} / \mathrm{v} \mathrm{H}_{2} \mathrm{SO}_{4} / \mathrm{H}_{2} \mathrm{O}$.

\subsection{Polarographic Measurements}

The analysis of iron content in the catalyst is achieved using voltammetric measurements. The voltammetric measurements were taken with a Metrohm 757 VA comp trace, with a three electrode system consisting of a hanging mercury drop electrode (HMDE) as the working electrode, an $\mathrm{Ag} / \mathrm{AgCl}$ reference electrode and a platinum counter electrode. The system is completely isolated from oxygen. This can be achieved by performing experiments under a stream of argon. The vessel used in the measurements was equipped with a magnetic stirrer, and thermostatted at $298.0 \pm 0.1 \mathrm{~K}$. The measurements include the preparation of samples of $10 \mathrm{mg}$ of iron phosphate in $10 \mathrm{ml}$ of $50 \% \mathrm{v} / \mathrm{v} \mathrm{H}_{2} \mathrm{SO}_{4} / \mathrm{H}_{2} \mathrm{O}$ solution. Bubbling the $\mathrm{H}_{2} \mathrm{SO}_{4} / \mathrm{H}_{2} \mathrm{O}$ mixture by argon for at least $1 \mathrm{~h}$ can assure removal of oxygen from the system. The mercury electrode is immersed in the solution under investigation and placed in a cell containing the reference electrode. Polarographic current-voltage curves can be recorded with a simple instrument consisting of a potentiometer or another source of voltage and a currentmeasuring device. The standard addition method was used to quantitatively determine the amount of iron (II) and iron (III) in the sample.

\subsection{Standard Addition Method}

The speciation of Fe(II) and Fe(III) can be done in the same sample. First the Fe(II) content was determined in the sample with iron (II) standard and afterwards Fe(III) was determined with $\mathrm{Fe}(\mathrm{III})$ standard without changing the sample solution. $20 \mathrm{ml}$ of sodium pyrophosphate solution $\left(\mathrm{Na}_{4} \mathrm{P}_{2} \mathrm{O}_{7}, 0.10 \mathrm{~mol} / \mathrm{l}\right)$ which was used as the background electrolyte and $100 \mu \mathrm{l}$ sample were transferred into the polarographic vessel. Three times $100 \mu \mathrm{Fe}$ (II) standard were added manually. Afterwards three times $100 \mu \mathrm{l}$ of $\mathrm{Fe}$ (III) standard were added to the same sample solution. Two replications were made to assure reproducibility.

\subsection{XRD M easurements}

Some polycrystalline iron phosphates were milled and inserted in glass capillaries on a rotating probe head. Powder X-ray diffractograms were collected on a STOE STADIP using Mo- $K \alpha$ radiation $(\lambda=0.7093 \AA)$ and a Gemonochromator in Debye-Scherrer arrangement. 


\section{Results and Discussion}

\subsection{Iron Phosphate Structures}

The iron phosphates $\left[\mathrm{C}_{4} \mathrm{H}_{12} \mathrm{~N}_{2}\right]\left[\mathrm{Fe}^{\mathrm{II}}\left(\mathrm{H}_{2} \mathrm{O}\right)_{6}\right]\left(\mathrm{HPO}_{4}\right)_{2}$ (1), $\mathrm{Fe}_{7}\left(\mathrm{PO}_{4}\right)_{5}\left(\mathrm{HPO}_{4}\right)$ (2) and $\left\{\left[\mathrm{Fe}^{\mathrm{II}}\left(\mathrm{H}_{2} \mathrm{PO}_{4}\right)_{2}-\left(\mu-4,4^{\prime}-\right.\right.\right.$ bipy) $\left.\left(\mathrm{H}_{2} \mathrm{O}\right)\right] \cdot \mathrm{H}_{2} \mathrm{O} \cdot(4,4$ '-bipy $\left.)\right\}$ (3) have been used in this work. The complexes are resynthesized according to synthetic approaches published elsewhere [7, 13, 15]. Powder X-ray diffraction was performed to test whether the prepared iron phosphates matched the simulated diffractograms from the single-crystal analysis. We found that there were excellent agreements between the diffractograms of measured and simulated patterns.

\subsection{Use of $\mathbf{N}$ anoporous $\mathrm{M}$ aterials as Catalysts}

The catalytic oxidation of cyclohex-2-enol by a molecular oxygen was studied using samples of porous iron (II) phosphates $\mathbf{1}, \mathbf{2}$, and $\mathbf{3}$. Reaction rates for the conversion of cyclohex-2-enol to the corresponding products by the reaction with air in the presence of porous iron (II) phosphates were quantitatively measured by GC/MS. When a mixture of cyclohex-2-enol and toluene (internal standard) was subjected to an oxidative catalytic test using porous iron (II) phosphates, there was no conversion of the toluene molecule. Toluene is too large to access the active metal sites within the framework. Also toluene has no active sites for oxidation processes. On the other hand, a conversion of cyclohex-2-enol has been found under the same conditions. Thus, the absorption initiates the catalytic oxidation reaction which implies that the successful catalytic reaction with porous iron (II) phosphate does indeed take place within the pores and/or by a surface reaction. Mixing of cyclohex-2-enol with dry air without the presence of porous iron phosphate polymers 1, 2, and $\mathbf{3}$ (blank trial) resulted in no oxidative conversions. As a result, it is suggested that cyclohex-2enol moved into preferential direction, i.e. in channel-like structures of porous iron phosphates. The oxidation products are shown in Scheme 1. Table 1 summarizes the results of catalytic studies using samples of porous iron (II) phosphates 1, 2, and $\mathbf{3}$.

The color of the solution produced during the catalytic reaction was monitored. The color changed gradually from colorless to brown. This can be explained by the formation of the new oxidation products during the catalytic reaction which have dark color (brown). The resulting products have been monitored and characterized using gas chromatography/mass spectroscopy. Fig. 1 shows GC/MS chromatograms obtained after injection of reaction products after different periods of times using the porous iron phosphate $\mathbf{2}$ as a catalyst, the other GC/MS chromatograms are not shown here. Three new peaks appeared in the chromatograms and the area of the new peaks was found to increase with the increase in reaction time. The molecular masses of the new peaks are: $114 \mathrm{~g} / \mathrm{mol}$ at $t_{R}=3.50 \mathrm{~min}, 114 \mathrm{~g} / \mathrm{mol}$ at $t_{R}=3.92 \mathrm{~min}$, $113 \mathrm{~g} / \mathrm{mol}$ at $t_{R}=4.60 \mathrm{~min}$ and $114 \mathrm{~g} / \mathrm{mol}$ at $t_{R}=5.05 \mathrm{~min}$ (where $t_{R}$ is a retention time). A small peak appeared at $3.73 \mathrm{~min}$ corresponds to a molecular weight of $98 \mathrm{~g} / \mathrm{mol}$ and a percentage yield about $2 \%$. These products correspond to the oxidization process of cyclohex-2-enol. Performing the method without the presence of porous iron phosphate resulted in a poor oxidation reaction $(5 \%$ conversion after $72 \mathrm{~h}$ ).

Fig. 2 shows a plot of area ratio of cyclohex-2-enol, epoxycyclohexanol, cyclohex-2-en-1,4-diol, 4-hydroxycyclohex-2-enone and cyclohex-2-en-1,4-dione with respect to toluene versus time. The oxidation of cyclohex2-enol results in a clear decrease in cyclohex-2-enol area ratio with an increase in the area ratios of the oxidation products.<smiles>OC1C=CCCC1</smiles>

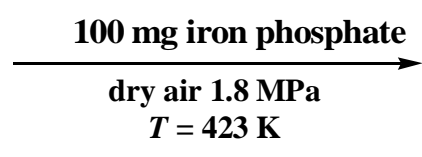

$T=423 \mathrm{~K}$
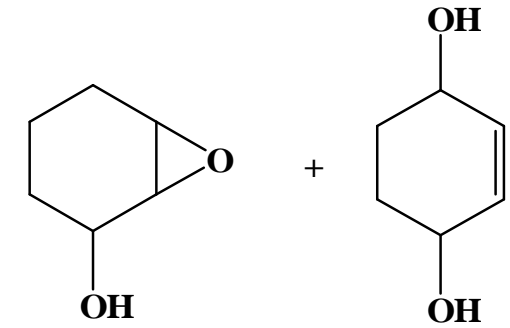
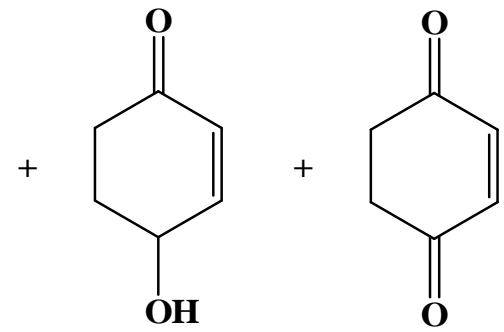

Scheme 1. Catalytic oxidative of cyclohex-2-enol using porous iron (II) phosphates, 1, 2, and $\mathbf{3}$ as catalysts, the catalytic reaction products are: epoxycyclohexanol, cyclohex-2-en-1,4-diol, 4-Hydroxycyclohex-2-enone, cyclohex-2-en-1,4-dione according to appearance in the scheme 
Total conversion percentage $(\%)$ of cyclohex-2-enol to its oxidation products as calculated from GC/MS results using porous iron phosphates 1,2 , and 3

\begin{tabular}{|c|c|c|c|c|c|c|c|c|}
\hline \multirow{2}{*}{ Iron complex } & \multicolumn{9}{|c|}{ Time, $\mathrm{h}$} & \multicolumn{6}{c|}{. } \\
\cline { 2 - 10 } & 0 & 6 & 12 & 24 & 36 & 48 & 60 & 72 \\
\hline 1 oxidation, \%* & 0.00 & 5.22 & 15.51 & 19.06 & 23.36 & 34.33 & 44.24 & 55.77 \\
\hline 2 oxidation, \%* & 0.00 & 4.81 & 12.94 & 20.27 & 24.55 & 31.24 & 40.73 & 59.19 \\
\hline 3 oxidation, \%* & 0.00 & 6.94 & 14.33 & 21.44 & 23.95 & 35.63 & 41.31 & 59.65 \\
\hline
\end{tabular}

Note: *total conversion of cyclohex-2-enol to its oxidation products. Calculated from summation of percentages of formation of epoxycyclohexanol, cyclohex-2-enol-3-ol, 4-hydroxy-cyclohex-2-enone and cyclohex-2-en-1,4-dione.

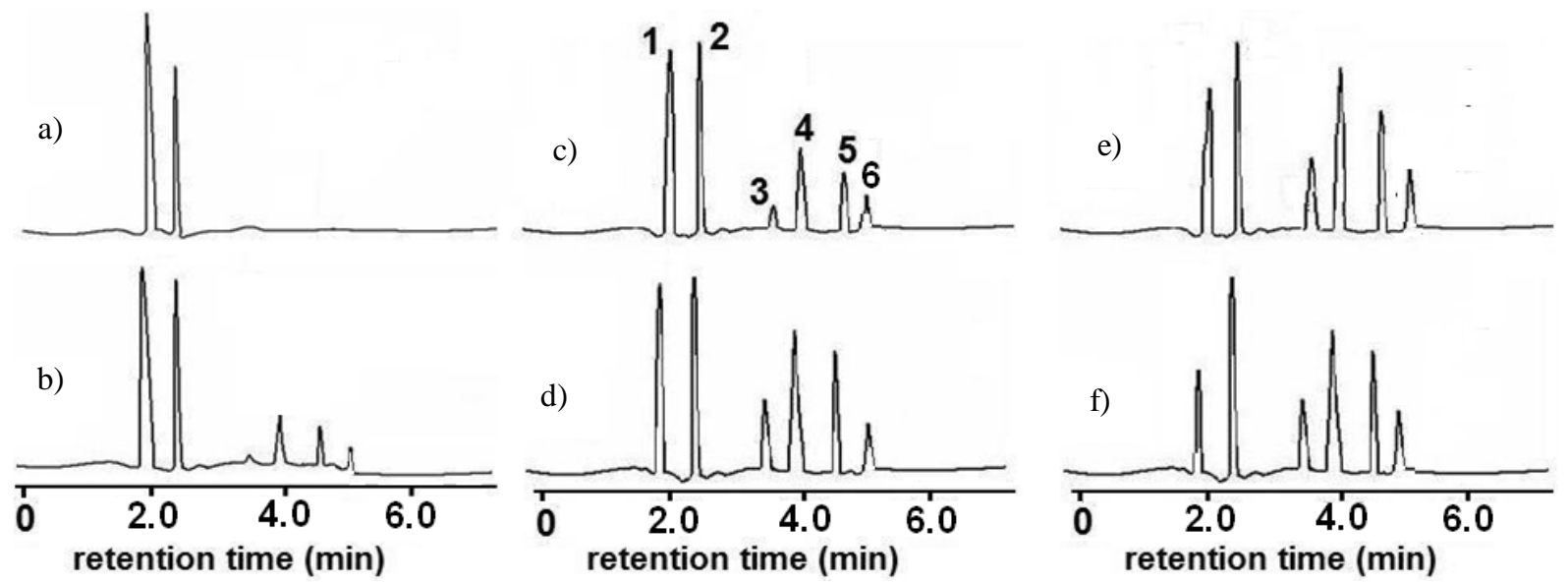

Fig. 1. GC/MS chromatograms resulting from the injection of reaction products after different periods of time using porous iron phosphate 2 as a catalyst: $0 \mathrm{~h} \mathrm{(a);12} \mathrm{h} \mathrm{(b);24} \mathrm{h} \mathrm{(c);} 36 \mathrm{~h}$ (d); $48 \mathrm{~h}$ (e) and $60 \mathrm{~h}$ (f). 1 - cyclohex-2-enol; 2 - toluene; 3 - epoxycyclohexanol; 4 - cyclohex-2-en-1,4-diol; 5 - 4-hydroxycyclohex-2-enone;

6 - cyclohex-2-en-1,4-dione

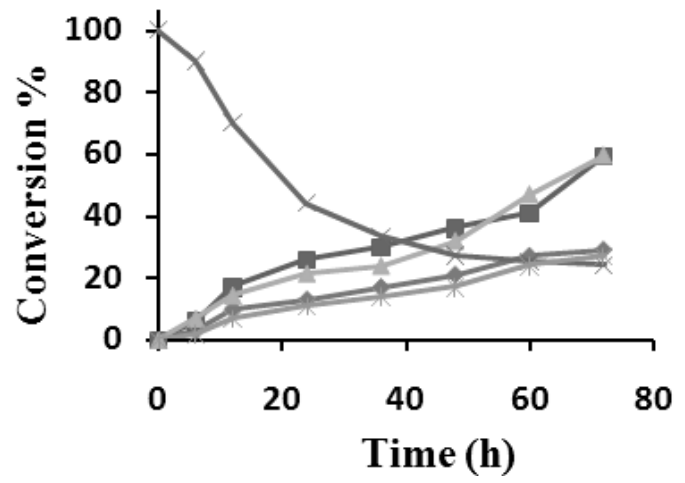

$\multimap$ cyclohex-2-en-1,4-dione

- cyclohex-2-en-1,4-diol

- 4-Hydroxy-cyclohex-2-enone

- cyclohex-2-enol

* epoxycyclohexanol

Fig. 2. Time $v s$. area ratio plot of the catalytic reaction from the data collected from GC/MS results after injection of the reaction products at different periods of times using porous iron phosphate 2 as a catalyst

\subsection{Polarographic Measurements}

The major purpose of the present work is to study the catalytic oxidation of cyclohex-2-enol by porous polymeric iron phosphate $\mathbf{1}, \mathbf{2}$, and $\mathbf{3}$. It was planned to follow the reaction by $\mathrm{GC} / \mathrm{MS}$ measurements. But, at the end of the reaction, it was noticed that the color of the catalytic material is converted from white or green to gray-black. This behavior is characteristic of oxidation of $\mathrm{Fe}$ (II) to $\mathrm{Fe}$ (III) to produce mixed valent $\mathrm{Fe}$ (II)/ $\mathrm{Fe}$ (III) complexes $[13,17]$. The dark color is due to intracharge transfer within the iron phosphate complexes [18]. This 
kind of conversion was the driving force to study the electrochemical properties of iron phosphates. An electrochemical technique was developed to determine $\mathrm{Fe}(\mathrm{II})$ and $\mathrm{Fe}(\mathrm{III})$ concentrations in a solution. The method involves measurements of current-voltage curves obtained when the voltage is applied to electrodes immersed in the solution being investigated. The differential pulse polarograms for Fe(II) and Fe(III) were obtained in sodium pyrophosphate medium as a supporting electrolyte. A sample solution was transferred into the polarographic cell. After purging with purified argon gas for $30 \mathrm{~min}$ the polarograms were recorded by sweeping the potential from -1.4 to $+0.05 \mathrm{~V}$ versus the reference electrode.

Calibration plots for the determination of $\mathrm{Fe}(\mathrm{II})$ and $\mathrm{Fe}$ (III) were prepared according to the procedure under the optimum conditions developed from its differential pulse polarogram with different concentrations.

Fig. 3 shows the polarographic results after carrying out catalytic reactions for $0,6,12,24,36$ and $48 \mathrm{~h}$ using porous iron phosphate 2 . The other polarograms for porous iron phosphates $\mathbf{1}$ and $\mathbf{3}$ are not shown here. Fig. 3a shows the polarograms resulting from the standard addition of ammonium ferrous sulphate hexahydrate and ammonium $\mathrm{Fe}(\mathrm{III})$ sulphate dodecahydrate to a sample of iron phosphate catalyst 2 after carrying out catalytic reactions for $12 \mathrm{~h}$. Fig. $3 \mathrm{~b}$ shows that mixing of $\mathrm{Fe}$ (II) phosphate with dry air and cyclohex-2-enol resulted in a decrease of the $\mathrm{Fe}$ (II) peak and increase of the $\mathrm{Fe}(\mathrm{III})$ peak. This behavior is characteristic of $\mathrm{Fe}$ (II) oxidation to Fe(III). Fig. 3c shows the standard addition curves for $\mathrm{Fe}$ (II) and $\mathrm{Fe}$ (III) species when porous iron phosphate $\mathbf{2}$ was used as the catalyst for $12 \mathrm{~h}$. It was found that $\mathrm{Fe}(\mathrm{II})$ and $\mathrm{Fe}(\mathrm{III})$ concentrations can be automatically and quantitatively calculated. The conversion percentage was also calculated.

Table 2 summarizes the conversion percentages after employing different porous iron (II) phosphates as catalysts. Before starting the catalytic reaction it was found that there was no $\mathrm{Fe}$ (II) to $\mathrm{Fe}$ (III) conversion. When catalytic reactions were carried out for $6 \mathrm{~h}$, conversion is clearly observed with values between 2.0 and $3.0 \%$ depending on the type of iron phosphate used. As the catalytic reaction time increases, the conversion percentage increases reaching a maximum after $72 \mathrm{~h}$ in the range of $41-45 \%$ depending on the type of iron phosphate used.

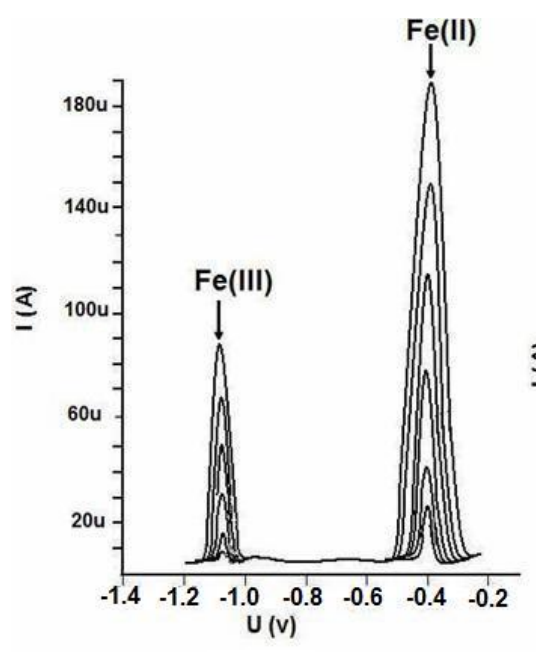

a)

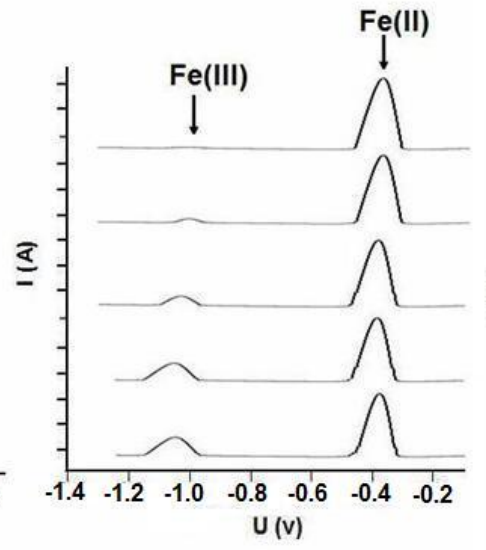

b)

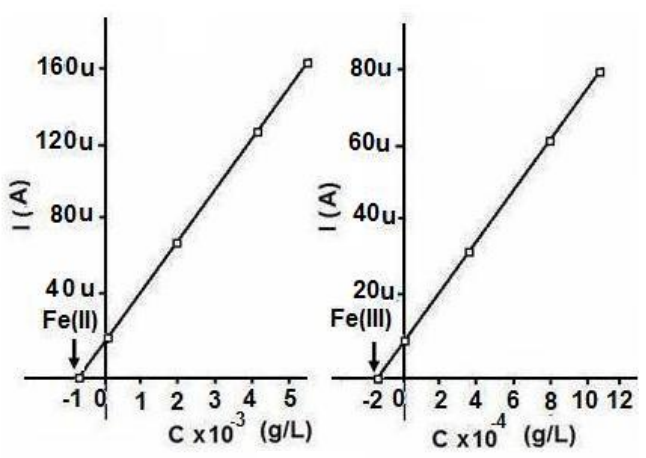

c)

Fig. 3. Pulse polarograms of $\mathrm{Fe}(\mathrm{II})$ and $\mathrm{Fe}(\mathrm{III})$ using standard addition method (standards used: $\mathrm{Fe}(\mathrm{II}) 4 \mu \mathrm{g} / \mathrm{ml}^{-1}, \mathrm{Fe}(\mathrm{III}) 2 \mu \mathrm{g} / \mathrm{ml}^{-1}$ ) (a); Polarograms resulting from measuring of iron phosphate (2) after performing catalytic reactions for different periods of time at 0 , 6, 12, 24 and 36 hrs from top to bottom (b); Standard addition curves done automatically to calculate Fe(II) and Fe(III) concentrations

(instrumental setting: deposition time $60 \mathrm{~s}$; deposition potential $0.8 \mathrm{~V}$; pulse amplitude $0.05 \mathrm{~V}$; pulse time 0.04 s; sweep rate $0.015 \mathrm{~V} \cdot \mathrm{s}^{-1}$; purge time $\left.300 \mathrm{~s}\right)(\mathrm{c})$

Table 2

Percentages of $\mathrm{Fe}$ (II) to $\mathrm{Fe}$ (III) conversion calculated from polarographic measurements after employing porous iron (II) phosphates 1, 2, and 3 as the catalyst for periods of time from 0 to $72 \mathrm{~h}$

\begin{tabular}{|c|c|c|c|c|c|c|c|c|}
\hline \multirow[t]{2}{*}{ Iron complex } & \multicolumn{8}{|c|}{ Time, $\mathrm{h}$} \\
\hline & 0 & 6 & 12 & 24 & 36 & 48 & 60 & 72 \\
\hline $1 \mathrm{Fe}(\mathrm{II})$ conversion, \% & 0.01 & 2.50 & 6.70 & 10.10 & 13.30 & 21.32 & 33.19 & 41.33 \\
\hline $2 \mathrm{Fe}(\mathrm{II})$ conversion, $\%$ & 0.06 & 2.90 & 7.90 & 12.34 & 19.98 & 27.12 & 39.10 & 44.13 \\
\hline $3 \mathrm{Fe}(\mathrm{II})$ conversion, \% & 0.04 & 3.10 & 8.80 & 15.12 & 22.24 & 31.53 & 38.76 & 45.31 \\
\hline
\end{tabular}




\subsection{Powder X-ray Diffraction and IR M easurements}

The powder X-ray diffraction results indicated that the materials were single-phase as there were excellent agreements between the diffractograms of measured and simulated patterns before the catalytic reaction is started.

The powder X-ray diffraction was also performed to test whether the frameworks of iron phosphates $\mathbf{1 , 2}$, and $\mathbf{3}$ were maintained on performing catalytic reactions. The results indicate that these complexes underwent a phase change as evidenced of changing the oxidation state of metal centres [7, 8]. Fig. 4 shows the measured powder $\mathrm{X}$-ray diffraction patterns after carrying out catalytic reactions for $0,6,12,24,36 \mathrm{~h}$ using porous iron phosphate $\mathbf{2}$. The other diffractograms for the iron phosphate $\mathbf{1}$ and $\mathbf{3}$ are not shown here. It was found that the peaks at $2 \theta=8.1$ and $2 \theta=8.8$ exhibit a shift to $2 \theta=8.9$ and $2 \theta=10.5$, respectively, after 6 and $12 \mathrm{~h}$. The measured powder X-ray diffraction patterns exhibit extra shifts to higher $2 \theta$ values when catalysis reactions were investigated for longer time periods. This shift to higher $2 \theta$ values is characteristic of oxidation $\mathrm{Fe}$ (II) to $\mathrm{Fe}$ (III) [19-22].

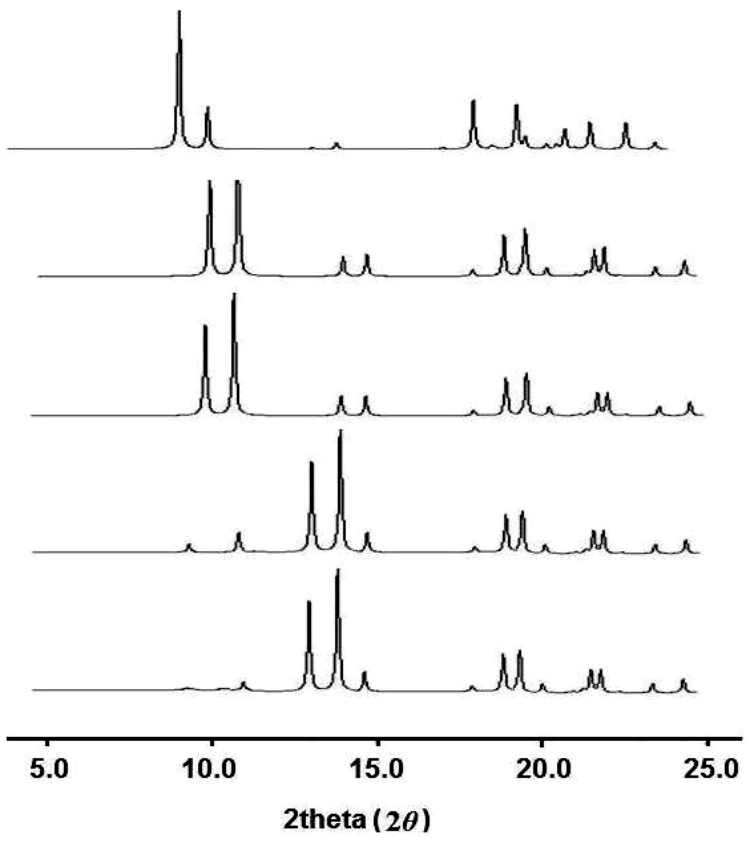

Fig. 4. Powder $\mathrm{X}$-ray diffraction spectra for iron phosphate $\left(\mathrm{C}_{3} \mathrm{H}_{12} \mathrm{~N}_{2}\right) \mathrm{Fe}^{\text {III }}{ }_{6}\left(\mathrm{H}_{2} \mathrm{O}\right)_{4}\left[\mathrm{~B}_{4} \mathrm{P}_{8} \mathrm{O}_{32}(\mathrm{OH})_{8}\right](2)$ after performing catalytic reactions for different periods of time: $0,12,24,36$ and $48 \mathrm{~h}$ from top to bottom

Moreover, the oxidation of $\mathrm{Fe}(\mathrm{II})$ to $\mathrm{Fe}(\mathrm{III})$ was recognized by the change of the color of the catalyst from colorless in case of pure Fe (II) to dark gray-black color indicating the formation of $\mathrm{Fe}(\mathrm{II}) / \mathrm{Fe}$ (III) mixed valence. FTIR spectroscopic measurements were performed on the porous metal phosphate $\mathbf{1}, \mathbf{2}$, and $\mathbf{3}$ composites during catalytic reactions and the results are found to be in agreement with literature values [23-25]. Since the catalytic reactions did not include a change in the type of coordination, and the polymeric complexes did not undergo substantial loss in the high temperature reactions, it is not expected to see a change in the IR spectra during the reaction. For longer periods of reaction time, it was noted that the bands become somewhat weaker but there were no shifts in the frequencies.

\section{Conclusions}

Porous iron phosphate polymers $\mathbf{1}, \mathbf{2}$, and $\mathbf{3}$ were resynthesized and the catalytic properties upon oxidation of cyclohex-2-enol were studied by means of polarography, GC/MS, FTIR and powder X-ray diffraction. The GC/MS data obtained from catalysis reactions indicated that the porous iron phosphates successfully catalyzed the oxidation of cyclohex-2-enol inside the microstructure of porous iron phosphates. Mixing of cyclohex-2-enol with dry air without the presence of porous iron phosphate polymers (a blank trial) resulted in no oxidative conversions. This indicated that cyclohex-2-enol moves into preferential direction, i.e. in channel-like structures of porous iron phosphates. Studying of the electrochemical properties of iron phosphates 1, 2, and $\mathbf{3}$ indicated that they underwent a phase change as evidenced of changing the oxidation state of metal centers. These results have been also supported by using powder X-ray diffraction measurements.

\section{Acknowledgments}

The author gratefully acknowledges the financial support of Tafila Technical University.

\section{References}

[1] Hortholary C., Coudret C.: J. Org. Chem., 2003, 68, 2167. https://doi.org/10.1021/jo026735z

[2] Ying J., Sobraningh D., Xu G. et al.: Chem. Commun., 2005, 3, 357. https://doi.org/10.1039/b412336k

[3] Beer P., Hayes E.: Coord. Chem. Rev., 2003, 240, 167. https://doi.org/10.1016/S0010-8545(02)00303-X

[4] Gupta K., Sutar A.: J. Mol. Catal. A, 2007, 272, 64. https://doi.org/10.1016/j.molcata.2007.03.025

[5] Moloto M., Nelana S., Moutloali R. et al.: J. Organomet. Chem., 2004, 689, 387. https://doi.org/10.1016/j.jorganchem.2003.10.027 [6] Shin J., Matyba P., Robinson N., Edman L.: Electrochim. Acta, 2007, 52, 6456. https://doi.org/10.1016/j.electacta.2007.04.068 [7] Mi J., Wang C., Chen N. et al.: J. Solid State Chem., 2010, 183, 2763. https://doi.org/10.1016/j.jssc.2010.09.008

[8] Gao Y., Zhang X., Wang P. et al.: Appl. Surf. Sci., 2017, 402, 336. https://doi.org/10.1016/j.apsusc.2017.01.134 
[9] Brigo L., Faustini M., Pistore A. et al.: J. Non-Cryst. Solids, 2016, 432, 399. https://doi.org/10.1016/j.jnoncrysol.2015.10.041 [10] Qin L., Qiao W., Zuo W. et al.: J. Solid State Chem., 2016, 239, 53. https://doi.org/10.1016/j.jssc.2016.04.021

[11] Abd-El-Aziz A., Todd E.: Coord. Chem. Rev., 2003, 246, 3. https://doi.org/10.1016/S0010-8545(03)00107-3

[12] Fratoddi I., Battocchio C., Furlani A. et al.: J. Organomet. Chem., 2003, 674, 10. https://doi.org/10.1016/S0022-328X(03)00156-6

[13] Huang Y., Schnelle W., Zhang H. et al.: J. Solid State Chem., 2009, 182, 920. https://doi.org/10.1016/j.jssc.2009.01.012

[14] Trapp O.: J. Chromatog. A, 2008, 1184, 160. https://doi.org/10.1016/j.chroma.2007.10.086

[15] Nijhuis T., Sacaliuc E., Beale A. et al.: J. Catal., 2008, 258, 256. https://doi.org/10.1016/j.jcat.2008.06.020

[16] Zhou B.-C., Yao Y.-W., Wang R.-J.: Acta Crystallogr. C, 2002, 58, i109. https://doi.org/10.1107/S0108270102009873

[17] Ezzatahmadi N., Ayoko G., Millar G. et al.: Chem. Eng. J., 2017, 312, 336. https://doi.org/10.1016/j.cej.2016.11.154

[18] Kang S., Bokare A., Park Y. et al.: Catal. Today, 2017, 282, 65. https://doi.org/10.1016/j.cattod.2016.03.009

[19] Coffey G., Hardy J., Pedersen L. et al.: Solid State Ionics, 2003, 158, 1. https://doi.org/10.1016/S0167-2738(02)00174-1

[20] Colson R., Floden A., Haugen T. et al.: Geochim. et

Cosmochim. Acta, 2005, 69, 3061.

https://doi.org/10.1016/j.gca.2005.02.005

[21] Somer G., Ünal Ü: Talanta, 2004, 62, 323.

https://doi.org/10.1016/j.talanta.2003.07.018

[22] Snegur L., Simenel A., Nekrasov Y. et al.: J. Organomet.

Chem., 2004, 689, 2473.

https://doi.org/10.1016/j.jorganchem.2004.05.001

[23] Moorthy L., Jayasimhadri M., Saleem S., Murthy D.: J. Non-

Cryst. Solids, 2007, 353, 1392.

https://doi.org/10.1016/j.jnoncrysol.2006.10.062
[24] Liu L., Liu D., Wang M., Du G.: Eur. Polym. J., 2007, 43, 2672. https://doi.org/10.1016/j.eurpolymj.2007.02.045

[25] Cahil A., Najdoski M., Stefov V.: J. Molec. Struct., 2007, 834, 408. https://doi.org/10.1016/j.molstruc.2006.11.049

Received: May 05, 2017 / Revised: June 08, 2017 / Accepted: September 01, 2017

\section{КАТАЛТТИЧНА ОКСИДАЦІЯ ЦИКЛОГЕКС-2-ЕНОЛА НА ЦЕОЛІТПОДІБНОМУ МАТЕРІАЛІ ПОРОШКОВОГО ЗАЛІЗА: ГХ/МС, ПОЛЯРОГРАФІЧНИЙ ТА ПОРОШКОВИЙ РЕНТГЕНОДИФРАКЦІЙНИЙ АНАЛІЗ}

\begin{abstract}
Анотація. Досліджено полімерні комплекси фосфатів пористого заліза $\left(\mathrm{NH}_{4}\right)_{4} \mathrm{Fe}_{3}{ }^{\mathrm{II}}(\mathrm{OH})_{2} \mathrm{~F}_{2}\left[\mathrm{H}_{3}\left(\mathrm{PO}_{4}\right)_{4}\right] \quad$ (1), $\left(\mathrm{C}_{3} \mathrm{H}_{12} \mathrm{~N}_{2}\right) \mathrm{Fe}_{6}{ }_{6}\left(\mathrm{H}_{2} \mathrm{O}\right)_{4}\left[\mathrm{~B}_{4} \mathrm{P}_{8} \mathrm{O}_{32}(\mathrm{OH})_{8}\right]$ (2) $\mathrm{ma}\left\{\left[\mathrm{Fe}^{\mathrm{II}}\left(\mathrm{H}_{2} \mathrm{PO}_{4}\right)_{2}-(\mu-\right.\right.$ 4,4'-bipy) $\left.\left(\mathrm{H}_{2} \mathrm{O}\right)\right] \cdot \mathrm{H}_{2} \mathrm{O} \cdot\left(4,4^{\prime}\right.$-bipy)\} (3) для окиснення циклогекс-2енолу. 3 використанням газової хроматографії/мас спектроскопї (ГХ/МС), ІЧ-спектроскопї та елементного аналізу визначено характеристику отриманих продуктів. Структурні властивості полімерних комплексів вивчені методом порошкового рентгенодифракційного та електрохімічного аналізу. Показано, щуо иі комплекси демонструють необоротний окисно-відновний процес і мають високу термічну стійкість. Встановлено, щзо комплекси зазнають фазових змін, про щэо свідчить зміна ступеня окиснення металевих центрів.
\end{abstract}

Ключові слова: каталітичне окиснення, цеолітподібний матеріал, ГХ/МС, полярографія, порошковий рентгенодифракиійний аналіз, ииклогекс-2-енол. 